\title{
Biedermeier man (Adalbert Stifter on happiness)
}

\author{
Svetlana Nikolajevna Averkina ${ }^{1 *}$ and Galina Ivanovna Rodina ${ }^{2}$ \\ ${ }^{1}$ Nizhny Novgorod Linguistics University, The Department of Foreign Literature and Intercultural \\ Communication, Nizhny Novgorod, Russia \\ ${ }^{2}$ Nizhniy Novgorod Linguistics University, Arazam brach, Department of History, Social Science and \\ Law, Arzamas, Russia
}

\begin{abstract}
The idea of an era is most often formed after a certain time after its end. This is the case with the Biedermeier era, the significance, and features of which have been appreciated only 50 years after its formal end. The name "man of the Biedermeier era" contains a provocation. The name refers us to the wonderful cultural period - the Renaissance, which formed the idea of "Titan-like personalities" and the greatest achievements. The Biedermeier era is a period of calm and peaceful life after the Napoleonic wars with no particular heroism or scale. The main plot of the works of this period is the search for social balance and personal happiness. However, upon closer examination, one can understand that this modest stage in the history of culture gives rise to a new type of genius who can see "the great in the small" (Adalbert Stifter, 1805-1868). The influence of this concept on the development of German literature can hardly be overestimated. The article deals with the work of the classic Austrian author, artist, and thinker A. Stifter, who is well-known to the German-speaking reader due to the creation of the concept of "the gentle law" ("das sanfte Gesetz"). The Russian reader is less familiar with the classic Austrian writer. This is because some of the codes and hidden meanings of Stifter's texts significantly differ from the ideas accepted in the Russian cultural world. The purpose of the study is to clarify some of them (the concepts of "happiness" and "gentle law"). The objectives of the research are determined by the need to give a brief description of the Biedermeier era in its national Austrian version and, in particular, in connection with A. Stifter's work. A hypothesis is put forward about the polystylistic nature of Biedermeier aesthetics, which influences the formation of the literary process in the German-speaking space. The novelty of the study consists in an attempt to look at the significance of the Austrian classic from a Russian perspective. This determines the theoretical framework of the study, built on the methods of comparative studies and conceptual text analysis.
\end{abstract}

Keywords: reception, Biedermeier era, tradition, concepts of "gentle law" and "happiness".

\footnotetext{
* Corresponding author: averkina.svetlanalunn@mail.ru
} 


\section{Introduction}

The article deals with the problem of reception of the Biedermeier era, in particular, the work of one of its most prominent representatives A. Stifter. Within the study, the Biedermeier era is contrasted with the Renaissance and Romanticism as the period of the search for a happy and "unheroic" peaceful life. This is the time of the Metternich reaction of 1815-1848 which ended in a huge explosion - the bloody bourgeois revolution of 1848. Unrest in the streets broke out in Vienna, leading to civil war [1:3-5].

After these events, A. Stifter, who by this period had created many texts, most of which were associated with life in the capital, moved to quiet Linz and engaged in socially useful activities in the field of education and the protection of cultural monuments. Among the liberal opposition, Stifter was known as a complete conservative, an opponent of revolutions, a "bard of bugs" and the happiness of private life [2: 124]. The culmination of his reflections of the Linz period was the policy text (in fact, the Biedermeier manifesto) "The Gentle Law". This essay was included by A. Stifter in the collection "Colourful Stones" as a preface. It is here that a panegyric to the "small world" is used, in which the Laws of the cosmos, physics, and morality are combined: the "great" shines through the "small" [3].

The body of research on the Biedermeier is quite vast, but only a few significant works can be named in Russian Germanic studies, especially in connection with A. Stifter's work. This is because individual codes and hidden meanings of the writer's texts do not coincide with those in the Russian cultural tradition. Some of them are considered in this study, the purpose of which is to analyze the basic concepts of A. Stifter's late work - the "gentle law" and "happiness". A hypothesis is proposed that the main character of Biedermeier is a "little man" in search of happiness, which is incredibly difficult to achieve even in peacetime. The novelty of the research consists in the study of the conceptual framework of A. Stifter's work from the Russian perspective.

\section{Methods}

The methodological framework of the study consists of works on comparative studies and comparative literary studies. This is due to the need to clarify the term "Biedermeier era", the scientific study of which began 50 years after its end. At the same time, the goal is to determine the role of the Biedermeier in the formation of the tradition of German literature and the reception of the work by the authors who were creating at that time (A. Stifter) in Russian literary criticism [3, 4: 43-75, 5].

Cultural-historical and biographical research methods of writers' work are auxiliary for achieving the set goal [6].

The method of conceptual analysis of the ideological sphere of the Austrian classic author's work is important, with an emphasis on several key axiologemes (Sittlichkeit, Mitte, Maß, Mitgefühl, Häuslichkeit) that are part of the semantic field of the concept of "happiness".

\section{Results and discussion}

\subsection{Stages of reception of A. Stifter's work in Russia}

The first mention of the name A. Stifter in an academic publication is found in the textbook edited by F.P. Shiller on Western European literature (1939) in the chapter "Bourgeois' regional' realists". The role that was assigned to the writer did not correspond to the scale of his personality and talent. Only twenty years later, two of Stifter's average novellas "The Old 
Seal" (translated by N. Averyanova) and "Granite" (translated by A. Averbakh) appeared in the collection "Austrian novellas of the 19th century" (1959). A real surge of interest in A. Stifter came in the 1970s when a collection of his novellas was published, edited by S.E. Shlapoberskaya. One started talking about the writer as a serious author of the "Vormärz" era.

The writer became a real breakthrough thanks to the outstanding Germanist A.V. Mikhailov, who for the first time called the creator of the novel "Indian Summer" a classic Austrian author. In 1967, in the five-volume edition of Monuments of World Aesthetics, the scholar wrote a chapter on Austria that included information about A. Stifter and the translation of his programmatic Preface to the Colourful Stones collection. According to Mikhailov, A. Stifter combined in his work the traditions of the Enlightenment, the spirit of Catholicism, interest in natural philosophy, idealism, managed to convey the originality of his country's culture and the main sentiments of his contemporary era [7: 461-479].

Since 1997, a whole series of A. Stifter's translated works have been published: the short story "Condor" (translated by N. Fadeeva), the novel "Indian Summer" (translated by S. Apt), a collection of three short stories ("Field Flowers", "Condor", "Highlands", trans. N. Fadeeva). In 1990, the first study of the work of the Austrian writer was published - L.N. Poluboyarinova's dissertation "Late Works by A. Stifter"; in 2005 - a book by N.E. Seibel "The Austrian Parallel", significant works by other authors.

Over the past decades, the name A. Stifter has invariably been mentioned in the pages of books on Austrian culture, in scholarly articles, and reference books on the literature of German-speaking countries.

\subsection{A. Stifter's conceptual framework in the context of Biedermeier aesthetics}

Traditionally, A. Stifter's works are viewed in the context of Biedermeier poetics. However, it can be assumed that the author's artistic world is built on the intersection of several traditions that influenced him to varying degrees in different periods of life.

For a long time, there was an idea that authors of the Biedermeier era were average or even mediocre. A. Stifter, F. Grillparzer, E. Mörike were criticized for their enthusiasm for trivial motives and naive plot moves. However, the appeal to idyllic images of rural life was motivated for A. Stifter with the ability to hide the tragic, intense experience of reality. It is no coincidence that the author of "Indian Summer" is considered a harbinger of modernism.

It is noteworthy that most works that most closely correspond to the concept of the Biedermeier were written by A. Stifter already after the 1948 revolution, at a time when the realistic method prevailed in literature. Moreover, A. Stifter's Biedermeier is a special phenomenon that requires particular consideration. Because of this, one should determine the scope of this term which arouses great interest and numerous discussions today.

The national component of the Biedermeier poses particular difficulty in understanding the originality of its development. In all German-speaking countries, the Biedermeier was assimilated in different ways, influenced by national cultural, and historical characteristics. In Austria, for example, Romanticism did not acquire clear outlines and did not become the main aesthetic trend of the first half of the 19th century. Undoubtedly, Romanticism significantly impacted the development of culture, influenced the musical and theatrical life of the empire. Moreover, the influence of Biedermeier proved so strong that it nearly blocked the development of realism and dissipated only at the birth of modernism, which, in its own way, also entered into a dialogue with Biedermeier [8].

The Austrian Biedermeier was largely formed under the influence of such a nationalhistorical phenomenon as Josephinism, which combines reformatory rationalism developed under the influence of French enlighteners, and a specific national spirit associated with the cultural diversity and baroque traditions of the Habsburg Empire [9: 83-102]. 
In addition to national features, it is necessary to note a number of the most important common European literary and cultural traditions that influenced the formation of A. Stifter and other authors of the Biedermeier era. This is, first of all, Burgher literature, the philistine drama of F.L. Schroeder, A. Kotzebue, A. Müller. Biedermeier only deepened the objectmaterial plane of depicting "bourgeois scenery", creating a feeling of hidden dramatic tension [10].

The most important role in the development of Biedermeier was played by the reception of Jean-Paul Richter's aesthetics with his unique ability to combine the soulfulness that touches any layman with a highly intellectual understanding of the comic, achieving the baroque lightness of a rogue novel. For A. Stifter, Richter became a literary mentor who taught Stifter to oppose the terrible events of history, the romantic struggle of passions, the clash of strong personalities with soft, deep humor [11].

Biedermeier draws closer to European sentimentalism thanks to the interest in nature which turns from an "artistic backstage" into a full-fledged character capable of telling its own story, full of internal collisions and dynamics.

When discussing the connections of the Biedermeier with the literature of the 18th century, one cannot ignore the figure of J.W. Goethe. Writers of the Vormärz era enthusiastically embraced his early lyrical poetry, the idyll "Hermann and Dorothea", the novel "Wilhelm Meister". The writers were attracted by Goethe's political position (moderately conservative), the ability to synthesize all areas and phenomena of life [12], interest in natural science, modern scientific concepts, and the question of the search for "happiness", which became one of the cornerstones for the authors of the Biedermeier era.

The main body of texts that focus on the concepts of "gentle law" and "happiness" paradoxically refers to the period of A. Stifter's acute liver disease and severe depression, which ended in suicide due to unbearable physical pain ("Colorful stones", "Indian summer", "Witiko", "Rural School", "Reading Book for Middle School") [13].

A chapter in the monograph "Langsamer" by S.N. Averkina is devoted to this problem. After a detailed conceptual analysis, it was concluded that the concept of "happiness" is realized in such axiologemes [14] as the moral law (Sittlichkeit), the ability to find a middle ground and draw the line in life (Mitte, Maß), the ability to sympathize and empathize (Mitgefühl), striving for domestic, private life (Häuslichkeit), which is filled with meaning through the action of the "gentle law" (das sanfte Gesetz), the ability to see the "great" in the "small" [15: 221-244].

\section{Conclusion}

1. In different periods of life, A. Stifter was influenced by different cultural phenomena. However, the work of the author of "Witiko" is characterized by the predominance of several philosophical and aesthetic concepts, which make it possible to speak of the deep involvement of the author's artistic world in the Biedermeier conceptual framework.

2. The most important sources of the Austrian version of Biedermeier, which influenced A. Stifter's work, were Enlightenment writers, representatives of German sentimentalism (J.P. Richter), late Romanticism writers, J.W. Goethe, perceived against the background of Josephinism.

3. The key concept of A. Stifter's work was the concept of "happiness" which was expressed in the writer's literary texts and socio-political articles. 


\section{References}

1. G. Hermann, Das Biedermeier im Spiegel seiner Zeit (1913). Accessed on: September 25, 2020. [Online]. Available: https://archive.org/details/dasbiedermeierim00hermuoft

2. F. Sengle, Die Formenwelt. Biedermeierzeit. Deutsche Literatur im Spannungsfeld zwischen Restauration und Revolution 1815-1848. Volume I (1971). Accessed on: October 26, 2020. [Online]. Available: https://archive.org/details/biedermeierzeitd0000seng_v5n1

3. E.R. Ivanova, Literatura nemetskogo bidermaiera [Literature of German Biedermeier] (Prometey, Moscow, 2007)

4. A. Schestag, Kunst und Kunstwerk, 6, 43-75 (1903)

5. A. Wiellbald, Wiener Bilder (Wien, 1833)

6. 6. V.G. Zinchenko, V.G. Zusman, Z.I. Kirnoze, Metody izucheniya literatury. Sistemnyi podkhod: Uchebnoe posobie [Methods of studying literature. Systemic approach: textbook] (Flinta, Moscow, 2002)

7. A.V. Mikhailov, Avstriya [Austria], in Istoriya estetiki. Pamyatniki mirovoi esteticheskoi mysli [The history of aesthetics. Monuments of global aesthetic thought]: Volume 3, 461-479 (Moscow, 1967)

8. N.E. Seibel, Austrian parallel: A. Stifter, H. Broch, R. Musil (Chelyabinsk State Pedagogical University, Chelyabinsk, 2005)

9. W. Baum, Jahrbuch des Wiener Goethe-Vereins, 99, 83-102 (1995/1996)

10. H. Bock, Theorie und Geschichte der burgerlichen Gesellschaft Aufbruch in die Bürgerwelt Lebensbilder aus Vormärz und Biedermeier (2014). Accessed on: January 04, 2021. [Online]. Available: https://hls-dhs-dss.ch/fr/articles/011202/2014-12-04

11. J. Berendes, Ironie - Komik - Skepsis: Studien zum Werk Adalbert Stifters [Irony comedy - skepticism: studies on the work of Adalbert Stifter] (de Gruyter, Berlin, 2009)

12. S. Braun, Naturwissenschaft als Lebensbasis? Adalbert Stifters Roman "Der Nachsommer" und weitere Schriften Stifters als Dokumente eines Versuches der Daseinsgestaltung auf der Grundlage naturwissenschaftlichen Forschens. (Stifter-Haus, Linz, 2006)

13. A. Stifter, Biedermeier (Kohlhammer, Stuttgart, 1998)

14. N.N. Kazydub, Vestnik irkutskogo gosudarstvennogo lingvisticheskogo universiteta [Irkutsk State Linguistic University Bulletin], 33, 132-137 (2009)

15. S.N. Averkina, Klyuchevye esteticheskie kategorii tvorchestva A. Stifter: nravstvennost (Sittlichkeit), krotkii zakon (das sanfte Gesetz), mera (Maß), svoboda (Freiheit), domashnost (Häuslichkeit) [Key aesthetic categories of A. Stifter's work: morality (Sittlichkeit), the gentle law (das sanfte Gesetz), measure (Maß), freedom (Freiheit), domesticity (Häuslichkeit)], in Langsamer. Monograph, 221-244 (Radonezh, Nizhnii Novgorod, 2020) 